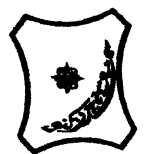

Bayero Journal of Pure and Applied Sciences, 10(2); 88 - 92

Received: April, 2017

Accepted: May, 2017

ISSN $2006-6996$

\title{
SYNTHESIS, CHARACTERIZATION AND ANTIMICROBIAL STUDIES OF METAL COMPLEXES OF MIXED LIGANDS : CITRIC ACID AND AMODIAQUINE
}

\author{
Lawal, A. ${ }^{1}$, Olowude, S. ${ }^{1}$, Bamigboye, M.O . ${ }^{2}$, Sa'ad, H.O ${ }^{1}$., Nnabuike, G.G ${ }^{1} .$, Yunus- \\ Issa, M.T . ${ }^{3}$ and Amolegbe, S.A. ${ }^{4}$ \\ ${ }^{1}$ Department of Chemistry, University of Ilorin, P.M.B 1515, Ilorin, Nigeria. \\ ${ }^{2}$ Department of Industrial Chemistry, University of Ilorin, Ilorin, Nigeria. ${ }^{2}$ \\ ${ }^{3}$ Federal College of Education, Osiele, Abeokuta, Ogun State, Nigeria \\ ${ }^{4}$ Department of Chemistry, Federal University of Agriculture, Abeokuta, Nigeria \\ *Correspondence author: amudat1112@gmail.com; +2348035850696
}

\begin{abstract}
$A$ range of d-block transition metals complexes of mixed amodiaquine and citric acid have been synthesized and characterised using microanalytical technique, elemental analysis, FT-IR spectroscopy and magnetic measurement. The results of the analytical and spectroscopic data revealed that both amodiaquine and citric acid acted as bidentate ligands in their mode of coordination with the metal ions. The citric acid bound through the carbonyl $(C=0)$ and hydroxyl groups to the metal ions while, amodiaquine coordinated through the nitrogen atom of the amine and oxygen donor atom of hydroxyl group; resulted in structures with octahedral geometry. Percentage composition and magnetic Bohr moment data indicated that all metal complexes were paramagnetic. Molar conductance measurement indicates that the complexes are non-electrolytes in nature. The antimicrobial activity of the ligands and their mixed complexes was carried out against $g(+)$ Pseudomonas aeruginosa, $g(+) E$. coli, $g(+) K / e b s i e l l a ~ p n e u m o n i a, ~ g(+) S t a p h y l o c o c c u s$ aureus and $g(+)$ Candida using Muller Hinton diffusion method. The citric acid and amodiaquine result showed low or moderate value from $(0.6-0.8)$ for all the metal complexes with the exception of the Cu (II) complex having inhibitory zones ranging from 1-0-1.3, 0.7-0.9 at 200 ppm respectively. Moreover, the free ligands were found being less active compared with their mixed complexes.
\end{abstract}

KEY WORDS: Citric acid, Amodiaquine, Complexes, Antimicrobial studies.

\section{INTRODUCTION}

The rapid developing field of bioinorganic chemistry is centred on the presence of coordination compounds in the living systems (Donald et al). The activity of transition metals has started the development of metal based drugs with promising pharmacological application and may offer unique therapeutic opportunities (Shazia et al ., 2010). The efficacy of a therapeutic agents is known to be enhanced upon coordination to a metal ion (Obaleye et a/2009). The fact that transition metals are essential metallic elements and exhibit great biological activity when associated with certain metal-protein complexes, participating in oxygen transport, electronic transfer reactions or the storage of ions has created attention in the study of systems containing these metals. On the other side, the ligands can not only control the reactivity of the metal, but also play critical roles in determining the nature of interactions involved in the recognition of biological target sites, such as DNA, enzymes and protein receptors. These variables provide enormous potential diversity for the design of metallodrugs (Cotton and 2001). . Hence, the application of metal complexes in medicine has continue to expand and yielded more effort in the research in bio-inorganic chemistry, with the hope of providing alternative chemotherapeutic agents to treat malaria parasites (Nicholas, 2002), Many studies have been reported on the synthesis of some common antimalarial drugs- metal complexes (Obaleye et al 2009; Ajibade and Kolawole; Adediji et a/2009).

Amodiaquine is a 4-aminoquinoline compound related to chloroquine, is used as an antimalarial and antiinflammatory agent. Amodiaquine has been shown to be more effective than chloroquine in treating chloroquine-resistant Plasmodium falciparum malaria infections and may afford more protection than chloroquine when used as weekly prophylaxis (Donno, 1989). The dominant use of citric acid is as a flavouring and preservative in food and beverages, especially soft drinks. Citrate salts of various metals are used to deliver those minerals in a biologically available form in many dietary supplements. The buffering properties of citrates are used to control $\mathrm{pH}$ in pharmaceuticals

( Hu et al 2010; Loffy et al 2007). The combination of two drugs give good combination therapy to rapid clearing parasite blood stream. It is hope that metal complex of to drugs or ligands will provide better therapeutic agent, which can solve the problem of parasite resistance. This paper

report the synthesis, characterization and antimicrobial studies of mixed complexes of Amodiaquine and Citric acid. 


\section{MATERIALS AND METHODS}

Citric acid and amodiaquine were obtained from Sigma Chemical Company, USA. All the solvents and other reagents were of analytical grade (Aldrich and sigma products) and were used without further purification. The metal salts used are $\mathrm{Cu}(\mathrm{II}), \mathrm{Hg}$ (II) and $\mathrm{Co}$ (II) hexahydrate. Five isolate of $\mathrm{g}(+)$ Pseudomonas aeruginosa, $\mathrm{g}(+) E$. coli, $\mathrm{g}(+)$ Klebsiella pneumonia, $\mathrm{g}(+)$ Staphylococcus aureus and $\mathrm{g}(+)$ Candida using were obtained from Department of Microbiology, University of Ilorin, Ilorin, Nigeria.

\section{Synthesis of metal complexes}

All the metal complexes were prepared according to the previously reported method by Adediji et a/ 2009. Citric acid ( $0.192 \mathrm{~g}, 1 \mathrm{mmol})$ and amodiaquine $(0.355 \mathrm{~g}, 1 \mathrm{mmol})$ were both dissolved in $10 \mathrm{ml}$ of ethanol. The solution were mixed thoroughly together in round bottom flask, introduced into a solution of chloride salts (1 mmol each) of mercury, copper, cobalt, and nickel hexahydrate, stirred under reflux for $3 \mathrm{hrs}$, at $78^{\circ} \mathrm{C}$ and left to stand for few days.

The product was filtered, washed with diethylether and dried in a dessicator for further analysis.

\section{Characterization methods}

Infrared spectra of the compound in $\mathrm{KBr}$ or $\mathrm{CsCl}$ pellets were measured in the ranges of 500 to 4000 $\mathrm{cm}^{-1}$ on Thermo Nicolet FTIR spectrometer. Microelemental analysis of Carbon, Hydrogen,Nitrogen, Oxygen, and Sulphur were carried out on PerkinElmer 204C micro analyzer, UV-Vis spectra were obtained on Beckman Coulter Du ${ }^{(R)} 730$ Scanning UVVis spectrometer. Magnetic moment was carried out by using Faraday balance. The melting point determination was carried out using Gallenkamp melting point apparatus. Conductivity measurement was carried out using Hanna EC 214 Conductivity meter with DMSO as control.

\section{Antimicrobial activity study}

Well diffusion method was applied for the antimicrobial screening test of the ligands and the mixed complexes. $\mathrm{T}$ he procedure employed by Ogunniran et al .,2013 as followed. Preparation of MHA: $38 \mathrm{~g}$ of commercially prepared Mueller Hinton agar was weighed and dissolved in $1000 \mathrm{ml}$ of water. The mixture was homogenized by shaking, stirring and slight heating. The conical flask containing the mixture was then plugged with cotton wool and wrapped with aluminium foil to make it air tight. The medium was autoclaved at $121^{\circ} \mathrm{C}$ for 15 minutes. The sterilized agar was allowed to cool to about $45^{\circ} \mathrm{C}$ and pour aseptically beside the flame into Petri dishes. The agar was then left to solidify completely.

The test organisms were reconstituted from the stocks on appropriate media (MHA for bacteria and PDA for yeast). The plates were incubated as follows: MHA at $37^{\circ} \mathrm{C}$ for 24 hours and PDA at room temperature (about $25^{\circ} \mathrm{C}$ ) for $48-72$ hours. Broth cultures of the organisms were used in seeding the agar each time the susceptibility test was done. The broth was standardized to 0.5 McFarland's standard equivalent $\left(0.05 \mathrm{ml}\right.$ of $1 \% \mathrm{BaCl}_{2}+9.95 \mathrm{ml}$ of $1 \%$ $\mathrm{H}_{2} \mathrm{SO}_{4}$ ). After seeding, the inoculars were uniformly spread with sterile swab sticks on the agar surface. The agar wells were then made with a cork borer which is sterilized by dipping in $70 \%$ ethanol and flaming each time. The agar plugs were removed and discarded. Aliquots (200-300 $\mu$ l) of the compounds were introduced aseptically into the wells in each plate using the micropipette with sterile tips. The compounds were then allowed to diffuse slowly and the plates were incubated accordingly; bacteria on NA or MHA for 24 hours at $37^{\circ} \mathrm{C}$ and yeast on PDA for 48-72 hours at room temperature $\left(25^{\circ} \mathrm{C}\right)$. The incubated plates were observed after the incubation periods for inhibition zones around the agar well and the zones (where present) were measured with a metre rule in $\mathrm{cm}$.

\section{RESULTS}

Reactions of $\mathrm{Co}(\mathrm{II}), \mathrm{Cu}(\mathrm{II})$ and $\mathrm{Hg}$ (II) chloride with citric acid and amodiaquine ligands in $1: 1: 1$ molar ratio in refluxing to yield $\left[M\left(\mathrm{~L}_{1}\right)\left(\mathrm{L}_{2}\right)\left(\mathrm{OH}_{2}\right)\right] \cdot \mathrm{Cl}_{2}$ represented by chemical equation as shown :

$\mathrm{MCl}_{2} \cdot 6 \mathrm{H}_{2} \mathrm{O}+\mathrm{L}_{1}+\mathrm{L}_{2}$

$M \mathrm{~L}_{1} \mathrm{~L}_{2}\left(\mathrm{OH}_{2}\right) \mathrm{Cl}_{2}+6 \mathrm{H}_{2} \mathrm{O} \quad$ Ethanol

Where $\mathrm{M}=\mathrm{Hg}, \mathrm{Cu}, \mathrm{Co}, \mathrm{Ni}, \mathrm{L}_{1}=$ Citric acid, $\mathrm{L}_{2}=$ Amodiaquine

\begin{tabular}{|c|c|c|c|c|c|c|c|c|c|}
\hline Compounds & $\begin{array}{l}\% \mathrm{C} \\
\text { found } \\
\text { (Calc) }\end{array}$ & $\begin{array}{l}\% \mathrm{H} \\
\text { found } \\
\text { (Calc) }\end{array}$ & $\begin{array}{l}\% \mathrm{~N} \\
\text { found } \\
\text { (Calc) }\end{array}$ & $\begin{array}{l}\mathrm{Cl} \\
\text { found } \\
\text { (Calc) }\end{array}$ & $\begin{array}{l}\% 0 \\
\text { found } \\
\text { (Calc) }\end{array}$ & $\begin{array}{l}\text { M.Pt. } \\
{ }^{\circ} \mathrm{C}\end{array}$ & colour & $\begin{array}{l}\text { Conductivity } \\
(\mu \mathrm{s} / \mathrm{cm})\end{array}$ & $\begin{array}{l}\% \\
\text { yield }\end{array}$ \\
\hline Amodiaquine ( $\mathrm{AMO}$ ) & $\begin{array}{l}37.50 \\
(37.35)\end{array}$ & $\begin{array}{l}4.17 \\
(4.06)\end{array}$ & - & - & $\begin{array}{l}58.33 \\
(58.30)\end{array}$ & 152 & White & 18.23 & - \\
\hline Citric acid (CIT) & $\begin{array}{l}67.50 \\
(67.52)\end{array}$ & $\begin{array}{l}6.23 \\
(5.96)\end{array}$ & $\begin{array}{l}11.81 \\
(11.57)\end{array}$ & $\begin{array}{l}9.96 \\
(9.95)\end{array}$ & $\begin{array}{l}4.50 \\
(4.54)\end{array}$ & 213 & Yellow & 15.34 & - \\
\hline $\begin{array}{l}{\left[\mathrm{Cu}(\mathrm{AMO})(\mathrm{CIT})\left(\mathrm{H}_{2} \mathrm{O}\right)\right.} \\
\left.{ }_{2} \mathrm{Cl}_{2}\right]\end{array}$ & $\begin{array}{l}31.72 \\
(31.76)\end{array}$ & $\begin{array}{l}3.59 \\
(3.47)\end{array}$ & $\begin{array}{l}7.01 \\
(6.95)\end{array}$ & $\begin{array}{l}5.33 \\
(5.29)\end{array}$ & $\begin{array}{l}31.80 \\
(31.76\end{array}$ & 310 & Yellow & 23.03 & 63 \\
\hline $\begin{array}{l}{\left[\mathrm{Hg}(\mathrm{AMO})(\mathrm{CIT})\left(\mathrm{H}_{2} \mathrm{O}\right)\right.} \\
\left.{ }_{2} \mathrm{Cl}_{2}\right]\end{array}$ & $\begin{array}{l}31.33 \\
(31.33)\end{array}$ & $\begin{array}{l}3.62 \\
(3.44)\end{array}$ & $\begin{array}{l}7.01 \\
(6.90)\end{array}$ & $\begin{array}{l}5.37 \\
(5.24)\end{array}$ & $\begin{array}{l}31.11 \\
(31.48)\end{array}$ & 342 & Green & 28.41 & 68 \\
\hline $\begin{array}{l}{\left[\mathrm{Co}(\mathrm{AMO})(\mathrm{CIT})\left(\mathrm{H}_{2} \mathrm{O}\right)\right.} \\
\left.{ }_{2} \mathrm{Cl}_{2}\right]\end{array}$ & $\begin{array}{l}31.78 \\
(31.76)\end{array}$ & $\begin{array}{l}3.65 \\
(3.47)\end{array}$ & $\begin{array}{l}7.03 \\
(6.95)\end{array}$ & $\begin{array}{l}5.34 \\
(5.29)\end{array}$ & $\begin{array}{l}31.78 \\
(31.76)\end{array}$ & 245 & Yellow & 17.32 & 65 \\
\hline
\end{tabular}


Bajopas Volume 10 Number 2 December, 2017

Table 2: Selected IR data $\left(\mathrm{cm}^{-1}\right)$ of the mixed complexes of Amodiaquine and Citric acid

\begin{tabular}{|c|c|c|c|c|c|c|}
\hline Compound & $\tilde{\mathbf{v}}(\mathbf{O H})$ & $\tilde{\mathbf{v}}\left(\mathbf{N H}_{2}\right)$ & ũ(NH) & $\tilde{\mathbf{v}}(\mathrm{C}=0)$ & $\tilde{\mathbf{v}(M-L)}$ & $\tilde{\mathbf{v}}(\mathrm{M}-\mathrm{OH})_{2}$ \\
\hline Amodiaquine ( $\mathrm{AMO}$ ) & $3418.94 \mathrm{br}$ & $3772.89 w$ & - & - & - & \\
\hline Citric acid (CIT) & $3410.26 \mathrm{br}$ & - & - & $1726.35 s$ & - & \\
\hline$\left[\mathrm{Cu}(\mathrm{AMO})(\mathrm{CIT})\left(\mathrm{H}_{2} \mathrm{O}\right)_{2} \mathrm{Cl}_{2}\right]$ & $3423.65 \mathrm{sh}$ & - & $3170.97 w$ & $1716.65 \mathrm{~m}$ & $596.00 \mathrm{~m}$ & $688.59 \mathrm{~m}$ \\
\hline$\left[\mathrm{Hg}(\mathrm{AMO})(\mathrm{CIT})\left(\mathrm{H}_{2} \mathrm{O}\right)_{2} \mathrm{Cl}_{2}\right]$ & $3421.72 \mathrm{~s}$ & - & $3172.90 \mathrm{~m}$ & $1726.29 m$ & $596.00 \mathrm{~s}$ & $688.58 \mathrm{~m}$ \\
\hline$\left[\mathrm{Co}(\mathrm{AMO})(\mathrm{CIT})\left(\mathrm{H}_{2} \mathrm{O}\right)_{2} \mathrm{Cl}_{2}\right]$ & $3413.15 b r$ & - & - & - & $606.63 \mathrm{~m}$ & - \\
\hline
\end{tabular}

Table 3: Electronic spectra and magnetic moment

\begin{tabular}{|c|c|c|c|c|c|c|}
\hline Compounds & $\begin{array}{l}\text { Electronic } \\
\text { configuration }\end{array}$ & $\begin{array}{l}\text { Ground } \\
\text { state }\end{array}$ & $\begin{array}{l}\text { Wavelength } \\
\text { nm }\end{array}$ & $\begin{array}{l}\text { Energy } \\
\text { cm }\end{array}$ & assignment & $\begin{array}{l}\text { Magnetic } \\
\text { bohr (BH) }\end{array}$ \\
\hline Amodiaquine ( $\mathrm{AMO}$ ) & - & - & - & 35088 & $n-n^{*}$ & \\
\hline Citric acid (CIT) & - & - & - & 43103 & $n-n^{x}$ & \\
\hline $\begin{array}{l}{\left[\mathrm{Cu}(\mathrm{AMO})(\mathrm{CIT})\left(\mathrm{H}_{2} \mathrm{O}\right)\right.} \\
\left.{ }_{2} \mathrm{Cl}_{2}\right]\end{array}$ & $d^{9}$ & $\mathrm{~s}$ & 454 & 22026 & ${ }^{2} \mathrm{~T}_{\mathrm{Ig}}(\mathrm{F}) \mathrm{-}^{2} \mathrm{~T}_{\mathrm{Ig}}(\mathrm{P})$ & 2.76 \\
\hline $\begin{array}{l}{\left[\mathrm{Hg}(\mathrm{AMO})(\mathrm{CIT})\left(\mathrm{H}_{2} \mathrm{O}\right)\right.} \\
\left.{ }_{2} \mathrm{Cl}_{2}\right]\end{array}$ & $d^{10}$ & ${ }^{1} \mathrm{~S}$ & 452 & 22124 & $n-n^{x}$ & 0.09 \\
\hline $\begin{array}{l}{\left[\mathrm{Co}(\mathrm{AMO})(\mathrm{CIT})\left(\mathrm{H}_{2} \mathrm{O}\right)\right.} \\
\left.{ }_{2} \mathrm{Cl}_{2}\right]\end{array}$ & $d^{7}$ & ${ }^{4} \mathrm{~F}$ & 386 & 25907 & ${ }^{4} \mathrm{~T}_{\mathrm{Ig}}(\mathrm{F}){ }^{-4} \mathrm{~T}_{2 g}$ & 3.99 \\
\hline
\end{tabular}

Table 4: The results of Antimicrobial activity Minimum inhibitory concentration (ppm) for ligands and mixed ligand $\mathrm{Co}(\mathrm{II}), \mathrm{Cu}(\mathrm{II})$ and $\mathrm{Hg}$ (II)

\begin{tabular}{|c|c|c|c|c|c|c|c|c|c|c|}
\hline \multirow{2}{*}{$\begin{array}{l}\text { Complexes/ ligands } \\
\text { Concentration }\end{array}$} & \multicolumn{2}{|c|}{ E. coli } & \multicolumn{2}{|c|}{ Pseudo.a } & \multicolumn{2}{|c|}{ Staphyl } & \multicolumn{2}{|c|}{$\begin{array}{l}\text { Klebsiella } \\
\text { spp. }\end{array}$} & \multicolumn{2}{|c|}{$\begin{array}{l}\text { Candida } \\
\text { spp. }\end{array}$} \\
\hline & $\begin{array}{l}\text { Zone } \\
\text { (200- }\end{array}$ & $\begin{array}{l}\text { hibition } \\
\text { ppm) }\end{array}$ & & & & & & & & \\
\hline Amodiaquine ( AMO) & 0.8 & 1.6 & 0.3 & 0.7 & 0.6 & 1.0 & - & 0.8 & 0.5 & 0.6 \\
\hline Citric acid (CIT) & 1.3 & 1.1 & - & - & 0.3 & 0.6 & 0.3 & 0.6 & 0.4 & 0.7 \\
\hline $\begin{array}{l}{\left[\mathrm{Cu}(\mathrm{AMO})(\mathrm{CIT})\left(\mathrm{H}_{2} \mathrm{O}\right)\right.} \\
\left.{ }_{2} \mathrm{Cl}_{2}\right]\end{array}$ & 0.9 & 0.8 & - & - & 0.7 & 0.9 & - & - & 1.0 & 0.6 \\
\hline $\begin{array}{l}{\left[\mathrm{Hg}(\mathrm{AMO})(\mathrm{CIT})\left(\mathrm{H}_{2} \mathrm{O}\right)\right.} \\
\left.{ }_{2} \mathrm{Cl}_{2}\right]\end{array}$ & 1.4 & 1.5 & - & - & 0.4 & 0.5 & - & - & 1.0 & 0.5 \\
\hline $\begin{array}{l}{\left[\mathrm{Co}(\mathrm{AMO})(\mathrm{CIT})\left(\mathrm{H}_{2} \mathrm{O}\right)\right.} \\
\left.{ }_{2} \mathrm{Cl}_{2}\right]\end{array}$ & 1.0 & 1.4 & - & - & 0.4 & 1.1 & 0.5 & 0.7 & 0.8 & 0.9 \\
\hline
\end{tabular}

\section{DISCUSSION}

The result of microanalytical and elemental analysis $(\mathrm{CHN})$ of the ligands and their complexes are presented in Table 1, The percentage composition of $\mathrm{C}, \mathrm{H}, \mathrm{N}, \mathrm{Cl}$ and $\mathrm{O}$ are in close agreement with the composition suggested for the complexes. The solubility of the metal complexes was compared with the ligands by dissolving them in warm and cold medium of some solvents; water, methanol, ethanol, acetone, chloroform and DMF and DMSO. However, they were found to be more soluble in DMF and DMSO. The complexes possess high decomposition temperature and were coloured. They are amorphous and stable in air.

The FT-IR spectral data are presented in table 2. The IR spectrum of the free Amodiaquine and Citric acid showed broad bands between 3418 and $3410 \mathrm{~cm}^{-1}$, which can be attributed to broad $\mathrm{OH}$ stretching vibrations. The positions of these bands were shifted to 3423,3421 and $3413 \mathrm{~cm}^{-1}$ the spectra indicating the involvement of $\mathrm{u}(\mathrm{OH})$ with metal centre during complexation. The ligands showed strong band around $1726 \mathrm{~cm}^{-1}$ which is arraigned to carbonyl moiety. In the complexes of $\mathrm{Hg}(\mathrm{II})$ and $\mathrm{Cu}(\mathrm{II})$, the peaks is slightly shifted to red region around 1726$1716 \mathrm{~cm}^{-1}$. This suggested that coordination of the metal is through the oxygen of the carbonyl group (Derrick et al 2000). The broad intensity bands of ligands were observed at the region $1714-1735 \mathrm{~cm}^{-1}$ of the spectra indicating carbonyl group. The ligands bind with the $\mathrm{Cu}$ (II) and $\mathrm{Hg}$ (II) ions in a bidentate manner through hydroxyl- $\mathrm{O}$ and carbonyl $-\mathrm{O}$ atoms respectively. Further, the two new bands appeared in the far infrared region at $596-606 \mathrm{~cm}^{-1}$ were assigned to $\mathrm{u}(\mathrm{M}-\mathrm{N})$ and $\mathrm{u}(\mathrm{M}-\mathrm{O}$ ) ( Lawal et al 2015). Thus, the IR spectral results provide evidence for bidentate coordination of the two ligands with metal ions.

The electronic spectra of the ligands and its metal (II) complexes were recorded in DMSO. The absorption bands at $38314 \mathrm{~cm}^{-1}$ and $34364 \mathrm{~cm}^{-1}$ attributed to $\Pi$ $\rightarrow \Pi$ and $n \rightarrow \Pi^{*}$ transitions for $L_{1}$ and $L_{2}$ respectively. $\mathrm{Hg}$ (II) complex band have been assigned to charge transfer or intra-ligand transition, $\mathrm{Hg}$ (II) is expected not to have $d-d$ transition because completely filled orbital. 
The Electronic spectra of Co(II) complex display two prominent bands. A low intensity broad band around $25907 \mathrm{~cm}^{-1}$ is assignable to ${ }^{4} \mathrm{~T}_{1 \mathrm{~g}}(\mathrm{~F}){ }^{-}{ }^{4} \mathrm{~T}_{2 \mathrm{~g}}$ transition. Another high intensity band around $25907-\mathrm{cm}^{-1}$ is due to $T_{1 g}(F)-T_{1 g}(P)$ transition. On the basis of electronic spectra distorted octahedral geometry around $\mathrm{Cu}$ (II) ion is suggested [10]. The $\mathrm{Cu}$ (II) complex showed magnetic moment $2.76 \mathrm{BM}$, is slightly higher than the spin-only value $1.73 \mathrm{BM}$ expected for one unpaired electron, which offers possibility of an octahedral geometry (Obaleye et al 2014). Also, magnetic Bohr for Co (II) complex which is $4.01 \mathrm{BM}$ is in close agreement with the measured value of octahedral shape. A tentative structure for the mixed metal complexes of Amodiaquine and Citric acid is proposed as:

\section{Proposed structure}

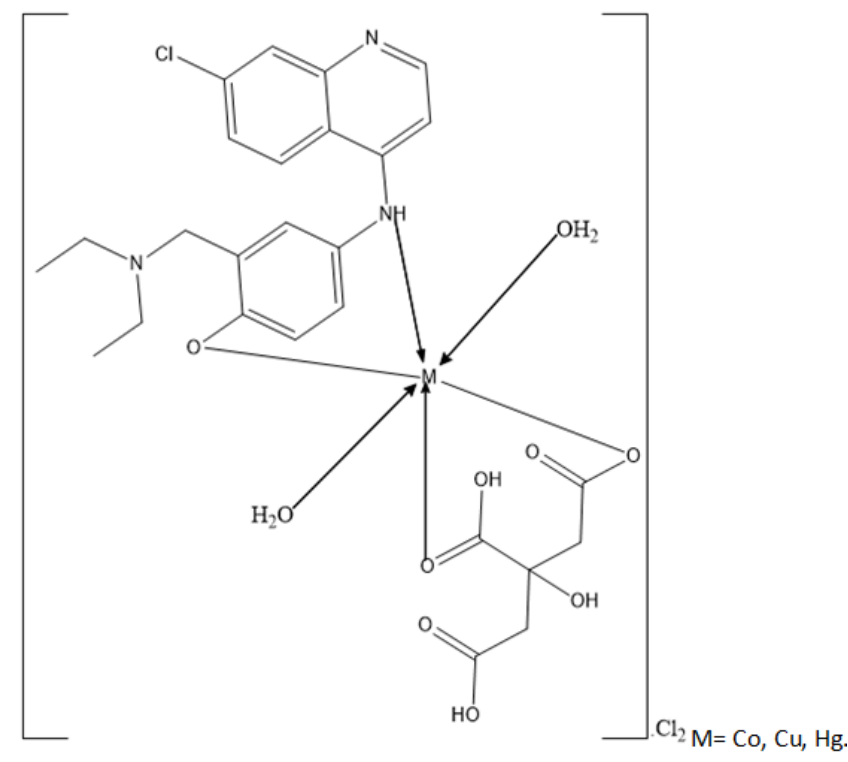

The ligands and mixed ligand complexes were screened for their antimicrobial activity against E.coli, $P$. Seudo.a and staphyl and for antifungal activity against klebisella spp and $C$. candida. The minimum inhibitory concentrations of all the compounds have been given in Table 4 . The antibacterial activity of the ligands and its complexes were studied at different concentrations. (200 ppm, 500ppm) by Muller Hinton agar diffusion method. . Cu(II) complex exhibits high activity towards Staphyl and candida spp. In vitro tests at minimum inhibitory concentration ranging from $0.9-1.0 \mathrm{ppm}$ compared to free ligands. $\mathrm{Hg}$ (II), and Co (II) complexes were active at minimum inhibitory concentrations at $200 \mathrm{ppm}$ against E.coli and candida spp when compared with standard drug at $200 \mathrm{ppm}$ and higher concentration showed no significant inhibition zone.

\section{REFERENCES}

Adediji, J. F., Obaleye, J.A., Adeniran, G.O.,Adebayo M. A., Olayinka E. T. (2009) "Fe(III) complex of mefloquine hydrochloride: Synthesis, antimicrobial and toxicological activities". African journal of Biotechnology.8(21): 5891-5896.

Ajibade, P and Kolawole,A. (2008): Synthesis, Characterization and in-vitro Antiprotozoal studies of Iron(II) Complexes of some Antimalarial drugs, J. Coord. Chem., 61(2): 3367- 3374

\section{CONCLUSION}

The mixed ligand $\mathrm{Co}$ (II), $\mathrm{Hg}$ (II) and $\mathrm{Cu}$ (II) complexes investigated during the present study demonstrated that the interaction of metal (II) chloride with citric acid and amodiaquine with carbonyl and hydroxyl group leads to complexes with $1: 1: 1$ stoichiometry and are found to be binuclear. The bidentate coordination mode of both type of ligands have been suggested on the basis of spectral evidences. All the complexes under studied showed to be consistent with octahedral geometry. Some of these complexes show higher activity against all the organisms compared with the free ligands..

\section{ACKNOWLEDGEMENT}

The authors wish to thank Rajrab Pharma Nig. Ltd., Ilorin, kwara state for donating the drugs. SAL appreciates the support of University of Ilorin Senate Research Grant for funding this project.

Cotton, F.A and Wilkinson, (2001) Overview of Transition metal chemistry, J.Chem. Soc., 1961

Derrick, M.R., Stulik, D and Landry, J.W (2000) Infrared spectroscopy in conservative science, scientific Tools for conservative, Getty Publications, 146-154

Donald, H., Brown, C and Smith, W.E(1990) The impact of metal ion chemistry in our understanding of Enzymes, $3^{\text {rd }}$ Ed., Academic Press, New $\quad 226$ 
Donno,L (1989). Drug combination in the treatment of malaria. J.Chemoth., 1(1): 52-58

Kulkami, D.A., Patil, S.A and Badami, P.S (2009). Electrochemical Properties of some transition metal Complexes : Synthesis, Characterization and In-vitro antimicrobial studies of $\mathrm{Co}(\mathrm{II})$,Ni(II), n(II), $\mathrm{Fe}(\mathrm{III})$ Complexes. Int, J. Electrochem Soc., 4. 717729

Lawal, A., Amolegbe, S. A.,Rajee A.O. Babamale H.F and Yunus-Issa, M. T. (2015) Synthesis, Characterization and Antimicrobial activities of some Mixed Ascorbic acid -Nicotinamide Metal Complexes. Bayero J. Pure and Applied Sciences , June 2015, 8 (1) 139- 142.

Lotfy, W.A.; Ghanem, K.M.; El-Helow, E.R.(2007). "Citric acid production by a novel Aspergillus niger isolate: II Optimization of process parameters through statistical experimental designs". Bioresource Technology, 98 (18): 3470-3477.

Nicholas, F. (2002). Biomedical uses and applications of Inorganic Chemistry; An overview Coord. Chem.Res., 1(4)
Obaleye, J.A., Balogun, E,A and Adeyemi, O.G (1999) : Synthesis and In-vivo effect of some metal drug complexes On malaria parasites. Biokemistri, 9(1), 23 - 27.

Obaleye, J.A., Lawal, A., Rajee A.O. Babamale H.F and Shittu, F.B. (2014) Synthesis, Characterization and Antimicrobial activity of Amodiaquine and Sulphadoxine Ligand Metal Complexes . Nigerian J. Biochemistry and Molecular Biology , 29 (2) p170- 178.

Obaleye, J.A., Caira, M.R and Tella, A.C (2009) Synthesis, Characterization and Crystal structure of tetrachlorocuprate and tetrabromocadmate salts of Antimalarial Mefloquine .Structural Chem, 20(5) 859-868.

Ogunniran, K.O., Adekoya, J.A., Siyanbola, T.O., Ajayeoba, T.A., Inegbenebor, A.I (2013): Synthesis, Antibacterial and Toxicology study of $\mathrm{Mn}$ (II), Co (II)and $\mathrm{Ni}(\mathrm{II})$ metal complexes of Sulfadoxine mixed with Pyrimethamine. SENTRA, Academic Publishers, British Colombia, 7(3): 2619-2627

Shazia, R, Muhammad, L, Haji,A and Amin. A (2010) Biotech and Mol. Biol. Rev, 5(2): 38-45 